Tourism Research Journal

E-ISSN: 2598-9839

2018, Vol. 2 No. 1

\title{
How To Develop Kampung Wisata Batik Pesindon As A Tourist Destination In Pekalongan Through SWOT Analysis
}

\author{
Rina Suprina $^{1 *}$ and Agrifina Amanda Nathania ${ }^{1}$ \\ 1Sekolah Tinggi Pariwisata Trisakti \\ rinasuprina@stptrisakti.ac.id
}

\begin{abstract}
Kampung Wisata Batik Pesindon (KWBP) is one of tourist destinations in Pekalongan, Indonesia, where people can find various products related to Batik. Although this area has been declared as a tourism village, it has been well known by tourists as there are not many tourists interested to come to this area. This study aims to determine the strategy that can be applied to develop Kampoeng Wisata Batik Pesindon as a good tourist attraction in Pekalongan City. The type of research used is descriptive with qualitative approach. The method of analysis used in this study is SWOT analysis. Then SWOT Matrix is formulated to obtain the strategy to develop KWBP. The result shows several development strategies in the category of human resources, product and marketing.
\end{abstract}

Keywords: SWOT analysis, Tourism Village, Tourist Destination

\section{A. Introduction}

Batik as one of Indonesia's cultural heritage has been well known worldwide as it has been registered and recognized by UNESCO in which Indonesia obtained copyright. Pekalongan, one of the cities in Central Java, Indonesia, is famous for its batik and has various types of batik. Society makes batik not only as a work of art, but has become a livelihood which can fulfill everyday life. Pekalongan City, on the other hand has also developed items that have magnetic power and are related to specification of batik product character, such as Batik Wholesale Market and Batik Museum,. 
Pekalongan is a small city which has potentials to be developed as a tourist destination. Therefore, some research have been done in certain areas to develop tourist destinations For example, Suprina, et al. (2018) investigated how to manage urban tourism of Kampung Sumbawan, a slum area in Pekalongan. which has dense population. The result found that the area is worth to be developed by doing improvement strategy, especially improving product and service. Some other areas have been declared as tourism village, such as Kampung Wisata Batik Kauman and Kampung Wisata Batik Pesindon.

Kampoeng Wisata Batik Pesindon (KWBP) has long been a region of batik concentration from generation to generation. It is an initiative of Pesindon people who want to form batik shopping area as an effort to revitalize home industry into shopping area. We can find 33 existing batik showrooms there. Kampoeng Wisata Batik Pesindon is also expected to increase the attractiveness of tourist areas that can provide a positive economic impact on the sectors of batik and non-batik economy, such as culinary and tourist accommodation (homestay). However, KWBP has not been able to develop into a good tourist attraction. Only a few number of tourist come to the area, making only a small contribution to batik sellers and community welfare there. Therefore, research should be done to find strategies how to manage the area to be an appealing tourist destination.

The purpose of this study is to examine the internal factors (strength and weaknesses) and external environment (opportunity and threat) facesd by KWBP. Then strategies to develop KWBP are formulated based on SWOT matrix analysis.

\section{B. Literature Review}

\section{Tourism Component}

In tourism activities the components of tourism will be interrelated in supporting the development of a region. The tourism component is divided into two factors, namely the supply component of tourism and the demand component of tourism. Tourism inventory includes everything that is offered to tourists including tourist attractions, accommodation, transportation, infrastructure, supporting facilities. Meanwhile, tourism demand is related, visitors and the community (Yoeti, 1996: 2).

\section{Kampung Wisata}

Kampung wisata is an area that offers authenticity in terms of social culture, customs, daily life, traditional architecture, village spatial structure presented in a form of integration of tourism component such as attractions, accommodation and supporting facilities. 


\section{Basic Concept of Tourism Area}

The basic concept of the tourism area is divided into two types, namely pure tourism and open tourism areas.

1) Pure tourism area is an area where all land is for the development and development of tourism facilities and infrastructures.

2) Open tourism area is an area whose main weight is for tourism development, which can also be used for other activities, such as settlements, forests, plantations, agriculture, industry (Ismayanti, 2010: 145).

\section{Tourism Objects}

Travel is an activity or part of the activity done voluntarily and is temporary to enjoy the object and the attraction of tourism. A tourist visits a place / area / country because he is attracted by something interesting and causes tourists to visit a place / region / country called attraction and tourist attractions (Mappi, 2001: 30).

According to Mappi (2001: 30-33) Tourism objects or Tourism attractions are grouped into three types, namely:

1) Natural attractions, for example: sea, beach, mountain (volcano), lake, river, fauna (rare), protected areas, nature reserves, natural scenery and others.

2) Cultural attraction, for example: birth ceremonies, (traditional) dances,

3) (traditional) traditional festivals, cultural festivals, woven (traditional), local textiles, performances (traditional), local customs, museums and others.

4) Artificial attractions, for example: sports facilities, games (kites), entertainment (jokes or acrobatics, magic), agility (horse riding), recreational parks, national parks, shopping centers and somemore

In building these tourism objects must pay attention to the socioeconomic conditions of the local community, local socio-cultural conditions, religious values, customs

\section{Tourist Destination}

According to Yoeti (1996:164), a good area to become an interesting tourist destination should have 3 criteria:

1) Something to see. The tourism area should have something that people can see and watch. In other words, the area should have specific attraction for tourists to come, which is different frown what is owned by other destinations.

2) Something to do. Tourists should be able to do something useful to get a feeling of happiness and relaxation supported by good recreation facilities such as theme parks or restaurant, especially restaurants which sell specialty food so that tourists wants to stay longer there.

Tourism Research Journal, Volume 2 (1), 2018 
3) Something to buy. It is the facilities for tourists to go shopping. Generally tourists prefer typical and iconic things from the area as a souvenir.

These three criteria are in line with the objectives of tourism marketing, namely targeting tourists to come to the area, stay longer, and spend money there.

\section{SWOT Analysis.}

According to Snelling (2012), SWOT analysis is a kind of analysis which consider the internal and external conditions. The stakeholder is analyzing the internal factors to understand strength (S) and weaknesses (W), and analyzing the external factors to understand opportunities $(\mathrm{O})$ and threats $(\mathrm{T})$.

Furthermore, Ronchetti composes SWOT matrix to compose strategic factors based on SWOT analysis as follows.

Table 1. SWOT Matrix

\begin{tabular}{|c|c|c|}
\hline INTERNAL & STRENGTH (S) & WEAKNESS (S) \\
\hline EXTERNAL & List of Strength & List of weaknesses \\
\hline OPPORTUNITY & S - O strategies & $\mathrm{W}$ - O strategies \\
\hline & $\begin{array}{l}\text { Use strength to reach } \\
\text { opportunity }\end{array}$ & $\begin{array}{l}\text { Decrease weaknesses by } \\
\text { utilizing opportunity }\end{array}$ \\
\hline THREAT & $\mathrm{S}-\mathrm{T}$ strategies & W-T strategies \\
\hline & $\begin{array}{l}\text { Use strength to avoid } \\
\text { threat }\end{array}$ & $\begin{array}{l}\text { Decrease weaknesses and } \\
\text { avoid threat }\end{array}$ \\
\hline
\end{tabular}

Source: Ronchetti, 2006

According to Salusu (2000), SWOT matrix uses several strategies as follows.

a) S-O Strategy by utilizing existing opportunity with the strength of organization (comparative advantage)

b) S-T strategy by mobilizing several strengths to achieve targets (mobilization)

c) W - O Strategy by choosing which factors are driven and which factors are delayed (investment/divestment)

d) W - T strategy, which requires caution or alertness in achieving goals (damage control).

The purpose of strategy selection is to ensure the accuracy of achieving the objectives. According to Sudirman.

\section{Research Methodology}

The research method used in this research is qualitative research. According Sugiyono (2007: 14) qualitative research methods is a research method based on post positivisme philosophy, used to examine the condition of

Tourism Research Journal, Volume 2 (1), 2018 
natural objects where researchers are as a key instrument. The study sample is part of the selected research subject and is considered to represent the entire population. This research is included in survey research, ie by observing limited samples to obtain a general picture of the entire population (Singarimbun \& Effendi, 1989). The sample in this research is Head of Culture Tourism, Youth and Sport, Head of Pundahuban Kampoeng Wisata Batik Pesindon, Batik Business Representative Kampoeng Batik Tour Pesindon, and Batik Batik Tourists Batik Pesindon as respondents interviewed amounted to 4 (four) people.

The author uses descriptive analysis technique that is by SWOT analysis (Strength, Weakness, Opportunities, Threats) to process data. Rangkuti (2006) explains that the SWOT analysis is the systematic identification of various factors to get formulated organizational strategy. This analysis is based on the logic that can maximize strength (Strength) and Opportunities but can simultaneously minimize Weakness and Threats.

SWOT analysis is used to compare external factors and internal factors. External factors consist of opportunities and threats, while internal factors consist of strengths and weaknesses. That way can be determined the various possible alternatives of strategy that can be executed.

The tool used in compiling the factors is the SWOT matrix. This matrix clearly illustrates how internal opportunities and threats can be tailored to internal strengths and weaknesses. This matrix can generate 4 (four) sets of alternative strategic possibilities ie SO, ST, WO and WT. The research method used in this research is qualitative research. According Sugiyono (2007: 14) qualitative research methods is a research method based on postpositivisme philosophy, used to examine the condition of natural objects where researchers are as a key instrument. Data collection techniques with triangulation (combined), data analysis is inductive / qualitative, and the results of qualitative research more emphasis on the meaning of the generalization. The study sample is part of the selected research subject and is considered to represent the entire population. This research is included in survey research, ie by observing limited samples to obtain a general picture of the entire population (Singarimbun \& Effendi, 1989). The sample in this research is Head of Culture Tourism, Youth and Sport, Head of Pundahuban Kampoeng Wisata Batik Pesindon, Batik Business Representative in Kampoeng Batik, and tourists in Kampung Batik Pesindon as respondents.

\section{Result}

\section{Kampung Wisata Batik Pesindon (KWBP)}

KWBP is located in Pekalongan, Central Java, established by community incorporated in community of batik pesindon lovers and local government of Pekalongan City. The area of KWBP is $162.564 \mathrm{~km} 2$ in the region of Bendan Kregon. KWBP provides various high quality batik and visitors have opportunity

Tourism Research Journal, Volume 2 (1), 2018 
to see how batik is made. There are 33 batik showrooms found in KWBP, with convenient rest area facilities for visitors. Besides buying batik, visitors in some showrooms can see how batik is made in the production house. They can also see various batik production such as traditional hand made batik and printed batik.

KWBP is supposed to be one of the interesting tourist destinations that can be visited by both local and foreign tourists. However, tourists visit to this area is still lacking. One of the weaknesses that can be seen from tourist attraction point of view is Kampoeng Wisata Batik Pesindon focuses on shopping activity only. Therefore, more in-depth analysis of Kampoeng Wisata Batik Pesindon is required to find strategies how to develop KWBP as an interesting tourist destination.

\section{SWOT Analysis Kampoeng Wisata Batik Pesindon}

The internal factor (Strengths and Weaknesses) and the external factor (Opportunity and Threats) of KWBP are analyzed as follow:

\section{a. Strength}

1) Human Resources (HR)

- There are many batik entrepreneurs in Kampoeng Wisata Wisata Batik Pesindon, either entrepreneurs who produce, or entrepreneurs who produce and open outlets / showroom batik.

- Many new batik entrepreneurs are popping up in the Regions Kampoeng Wisata Batik Pesindon.

2) Product

- Patterns, motifs and colors of batik in Kampoeng Wisata Area Batik Pesindon is superior to other places.

- The quality of batik products are always awake.

- There are various products of batik products offered in the Region Kampoeng Wisata Batik Pesindon.

3) Marketing

- The location of KWBP is strategically located in the middle of the city, making it easier for tourists to visit Kampoeng Wisata Batik Pesindon, especially before there is a toll road, Kampoeng Wisata Batik Pesindon is always passed by travelers.

- The location of batik outlets are many, freshly prepared spread in the area of Regions Kampoeng Wisata Batik Pesindon.

- Availability of art and cultural value that appeals to tourists. One of the existing religious arts of Kampoeng Wisata Batik Pesindon is the art of Tombo Ati. 
- There is a unique wall that is the main attraction for tourists who visit the Kampoeng Tourism Area Batik Pesindon.

b. Weaknesses

1) Human Resources

- High level of individualism among entrepreneurs.

- In the past community stewardship, members of Kampoeng Wisata Batik Pesindon majority community are entrepreneurs, due to the busyness of each member, therefore they rarely gather so that the Kampoeng Batik Pesindon Tour Group is not running well.

- Low knowledge of human resources either entrepreneur, batik, or community around Kampoeng Wisata Batik Pesindon about the basics of tourism, although the area of Pesindon has become a tourist village.

- The successor generation of batik in Kampoeng Wisata Batik Pesindon which decreases with time. Lack of regeneration of batik. Especially the writing batik.

2) Product

- Kampoeng Wisata Batik Pesindon does not have a special superior product only found in Kampoeng Wisata Batik Pesindon, on average every batik product in Kampoeng Wisata Batik Pesindon can be found in different store. (Does not have a special characteristic).

- Similarity of batik products, both in Kampoeng Wisata Area Batik Pesindon or existing in the city of Pekalongan, causing the price of products that can not survive and tend to be down due to business competition.

3) Marketing

- There is no marketing through print or electronic media about Kampoeng Wisata Batik Pesindon, so there are still many tourists who do not know about Kampoeng Wisata Batik Pesindon.

- Kampoeng Wisata Batik Pesindon not have a special website that promotes Kampoeng Wisata Batik Pesindon.

- Social media platform Kampoeng Wisata Batik Pesindon like Instagram or Youtube Channel that has been made not updated regularly.

- During this time, Kampoeng Wisata Batik Pesindon only focused on shopping only, so it has not become a worthy tourist attraction to visit.

- Still minimal event held in Kampoeng Area Batik Tour Pesindon to add tourist attraction.

- Pekalongan City Government, especially the Department of Tourism, Culture, Youth and Sports (DINPARBUDPORA) Pekalongan City, has no integrated planning regarding promotion or marketing

Tourism Research Journal, Volume 2 (1), 2018 
How To Develop Kampung Wisata Batik Pesindon As A Tourist Destination In Pekalongan Through Swot Analysis

Kampoeng Wisata Batik Pesindon Tourism, especially short-term, medium-term planning and long-term planning.

\section{c. Opportunities}

1) Human Resources (HR)

- SDM in Kampoeng Wisata Batik Pesindon and Pekalongan City Government, especially Department of Tourism, Culture, Youth and Sports (DINPARBUDPORA) can cooperate with institutions or agencies that specialize in tourism, such as the example of Tourism High School, to develop knowledge of tourism in Kampoeng Wisata Batik Pesindon.

- The batikers in Kampoeng Wisata Batik Pesindon area can perform batik training for the people around the Kampoeng Area Batik Tour Pesindon to overcome the threat of regeneration batik began to decrease.

- Batik makers in Kampoeng Wisata Batik Pesindon can perform batik training for tourists who come to visit Kampoeng Wisata Batik Pesindon.

2) Product

- With the use of batik in various institutions and institutions either government or private, can increase purchasing power in Kampoeng Wisata Batik Pesindon.

- In addition to using chemicals, making batik can made with natural coloration, such as blue or biron example made from Katu tree, as well as various other natural colors that can be taken from other plants. This becomes an opportunity that makes batik products in Kampoeng Wisata Batik Pesindon has its own characteristics / special.

3) Marketing

- With the development of marketing through cyberspace / online, Kampoeng Wisata Batik Pesindon can utilize online media platform well to market Kampoeng Wisata Batik Pesindon, as a tool to attract tourists to visit Kampoeng Wisata Batik Pesindon.

- Kampoeng Wisata Batik Pesindon can develop tourism that gives priority to the atmosphere that emphasizes the philosophy of batik, as well as the life of batik entrepreneurs and batik workers in Kampoeng Wisata Batik Pesindon.

- Tourism opportunities that can be developed in Kampoeng Wisata Batik Pesindon Besides shopping tour is art and culture tourism and culinary tour.

- Organize various events or festivals held in Kampoeng Tourism Area Batik Pesindon.

Tourism Research Journal, Volume 2 (1), 2018 


\section{d. Threat}

1) Human Resources (HR)

Business competition among the businessmen who prioritize the ego of each individual can be a threat to the development of a tourist area to become a tourist attraction.

2) Product

Rising prices of raw materials in the manufacture of batik became one of the threats in the process of making batik. This can result in a rise in the price of the product.

3) Marketing

- If Kampoeng Wisata Batik Pesindon only focuses on shopping tourism, then Kampoeng Wisata Batik Pesindon will be threatened by the existence of good batik selling places in Pekalongan City, such as the example of Wholesale Sentono, as well as batik selling place in other cities.

- Competition promotion with other tourist attractions arising from the effects of village funds, if Kampoeng Wisata Batik Pesindon not develop a tour that has its own distinctive, such as tourism that prioritizes the philosophy of batik, it can be a threat in the development of Kampoeng Wisata Wisata Batik Pesindon.

- Location Kampoeng Wisata Batik Pesindon area that is too close to other batik village in Pekalongan City.

\section{E. Discussion}

Based on the MATRIX SWOT results that are discussion on human resource development strategy, product development strategy, and marketing development strategy.

\section{Human Resource Development Strategy (HR)}

Utilizing the opportunities that arise with the many batik entrepreneurs who produce batik and open outlets / showroom batik, namely by empowering the existing batik workers to conduct batik training for local communities in Kampoeng Wisata Batik Pesindon to regenerate the existing batik workers in the Area Kampoeng Wisata Batik Pesindon.

Developing and maintaining the unique murals that exist around Kampoeng Wisata Batik Pesindon area. The local government can cooperate with the institutions engaged in the arts. Experts in the arts can work with local communities to decorate areas. The decorated area will become a special attraction for tourists who come to visit.

Tourism Research Journal, Volume 2 (1), 2018 
Conducting batik training for visiting tourists Kampoeng Tourism Area Batik Pesindon. This training can be held and focused in the secretariat of Kampoeng Paguyuban Wisata Batik Pesindon, the tourists can visit the secretariat if they want to participate in batik training.

Developing the readiness of the local government employees and community by providing a training of tourism knowledge, such as sapta pesona, service excellence, and basics of hospitality and tourism sector.

DISPARBUDPORA Kota Pekalongan and Paguyuban Kampoeng Batik Tour Pesindon can cooperate with the institutions engaged in tourism such as the example of the College of Tourism to develop the potential that exists in Kampoeng Wisata Batik Pesindon Tourism to be a worthy tourist attraction visited by tourists.

In order to develop Kampoeng Wisata Batik Pesindon Area becomes a tourist attraction favored by tourists, batik entrepreneurs in Kampoeng Wisata Batik Pesindon must be united and work hand in hand in developing tourism potential in Kampoeng Wisata Batik Pesindon. This is necessary so that the existing tourism potential can be developed. As a result, Kampoeng Wisata Batik Pesindon Tour can attract tourists to come to visit, and can overcome the threat from the existing batik shop in Pekalongan City, such as Batik Wholesale, and other tourist villages adjacent to Kampoeng Wisata Batik Pesindon.

\section{Product Development Strategy}

Develop natural coloring by using natural materials so it can be a special product Kampoeng Wisata Batik Pesindon. Optimize one of the strengths of products offered at Kampoeng Wisata Batik Pesindon is a strength in maintaining the quality of batik products and patterns, batik motifs and colors are superior to other places. This needs to be done in order to avoid the threat of rising raw material prices that lead to rising product prices. If product quality is maintained, even though the price of the product rises, the buyer is not reluctant to buy the product.

\section{Marketing Development Strategy}

DISPARBUDPORA Pekalongan City in cooperation with Paguyuban Kampoeng Wisata Batik Pesindon and local people to create an annual event held in Kampoeng Wisata Batik Pesindon. The event can contain the art of Kampoeng Wisata Pesindon, batik bazaar, fashion show etc. This event can be a tourist attraction to visit.

DISPARBUDPORA Kota Pekalongan can cooperate with Paguyuban Kampoeng Batik Pesindon Tour to develop arts and culinary tours. Things that can be done by optimizing the existing art in Kampoeng Wisata Pesindon. In addition to optimizing the arts, things can be done to develop a typical culinary Pesindon. This needs to be done so that tourists who visit not only do shopping

Tourism Research Journal, Volume 2 (1), 2018 
activities, but tourists can see the arts that exist and at the same time can taste the typical cuisine Pesindon.

Utilizing the number of businessmen and batik workers in Kampoeng Wisata Batik Pesindon. Things that can be done is to develop a tour that features the philosophy of batik, both in terms of life of batik entrepreneurs, batik workers and the process of making batik.

Optimizing the use of online media into a marketing tool to market tourism in Kampoeng Wisata Batik Pesindon Tourism by updating Kampoeng Wisata Batik Pesindon in social media platform Kampoeng Wisata Batik Pesindon regularly and periodically.

Promotional activities that could be done are printing brochures about Kampoeng Wisata Batik Pesindon as one of the promotion and marketing media, and place them in public places, such as hotels, stations, etc.

Create a special website about Kampoeng Wisata Batik Pesindon. Inside the website contains:

- The history of Kampoeng Wisata Batik Pesindon origin

- Activities that can be done in Kampoeng Wisata Batik Pesindon, such as batik activities, shopping, culinary tours, art tours, etc.

- Showrooms in Kampoeng Wisata Area Batik Pesindon.

- Hotels or inns around Kampoeng area Batik Pesindon Tour.

- Events that will and are taking place in the Region Kampoeng Wisata Batik Pesindon.

- Photos of Kampoeng Wisata Batik Pesindon.

Integrated planning in short, medium, and long term about marketing or promotion of Kampoeng Wisata Batik Pesindon are required. It needs to be well planned in order to overcome the threats that come from ttourist attractions outside the area.

Tablel 2. Strategies based on SWOT Matrix

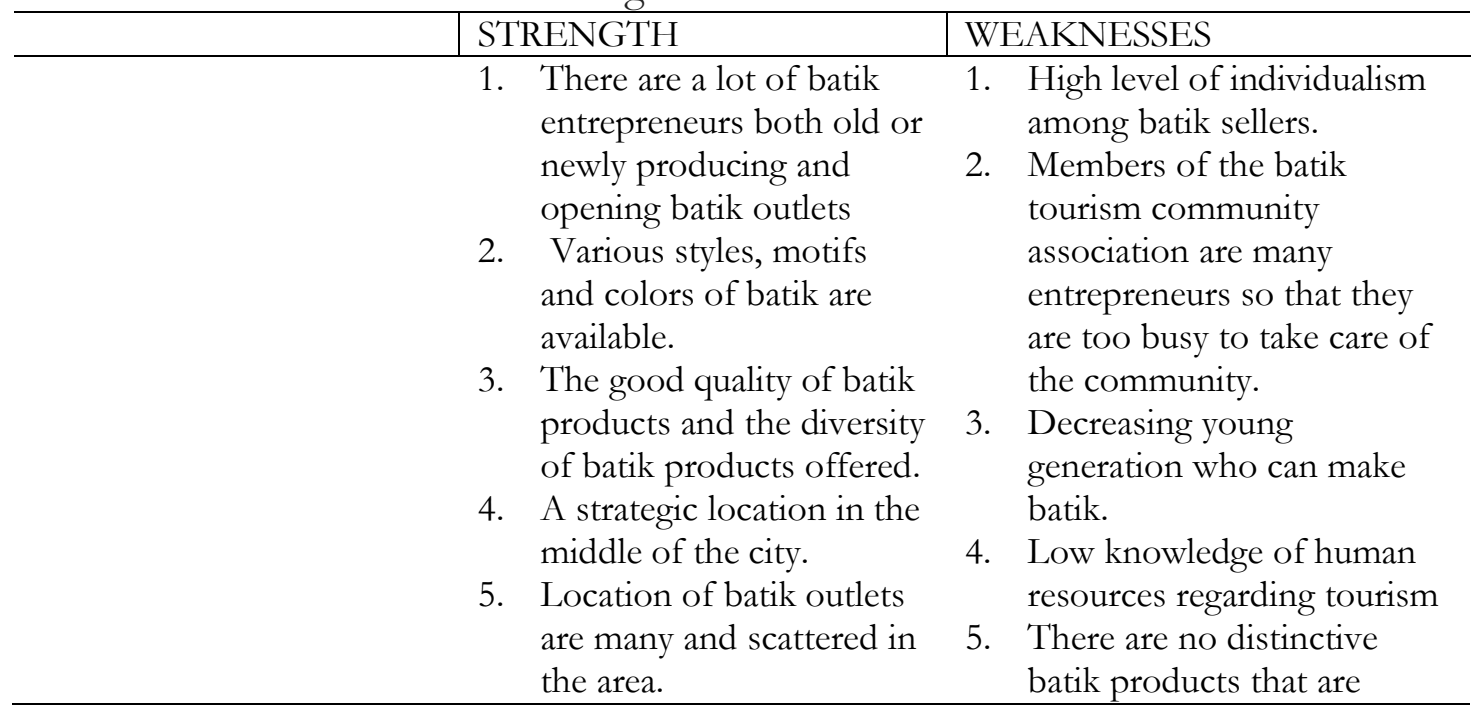

Tourism Research Journal, Volume 2 (1), 2018 
6. There are interesting arts and cultural traditions such as the art of tombo ati

7. There is a unique mural on the wall that is the main attraction.

different from other places.

6. Product prices tend to fall due to business competition

7. There is no marketing through certified or electronic media. Social media like Youtube Channel is not updated regularly and no special website to promote KWBP

8. Only focused on shopping tours. There are no other tourist activities.

OPPORTUNITY

1. The opportunity to build cooperation between community, local government, and institutions engaged in tourism such as industry and academics

2. The increasing interests of local and foreign tourists on batik, including the process of making batik.

3. The increasing use of batik uniform in institutions can increase the purchases of batik.

4. Batik coloring can be made with natural dyes, the opportunity to have distinctive batik characteristics.

5. The development of cyberspace for digital marketing.

6. Opportunities to organize events to develop art, culture and culinary tourism in addition to shopping
SO strategy

- Establish the cooperation between KWBP

community leader, government of Pekalongan to develop art and culinary tourism.

- Develop unique mural around the area by working with experts in the arts.

- Take advantage of existing batik entrepreneurs and workers to develop package tours that highlight the philosophy of batik.

- Conducting batik making activities for visiting tourists
WO strategy

- Increase the community readiness by cooperating with tourism institutions. For example, training on tourism awareness and excellent service for batik sellers and other community members

- Develop natural coloring so it can be a typical product of batik.

- Optimize the utilization of online media to market the area. Update social media on a regular basis.

- Conduct promotional activities through print brochures and store in public places such as hotels, stations etc.

- Create a special website about Pesindon Batik Tourism Village which contains village origins, available tourism activities, names of existing batik showrooms, lodging around the area, schedule of events, and photos of the area

- Develop existing potential by collaborating between disparbudpora, associations, and tourism agencies such as the Trisakti STP 


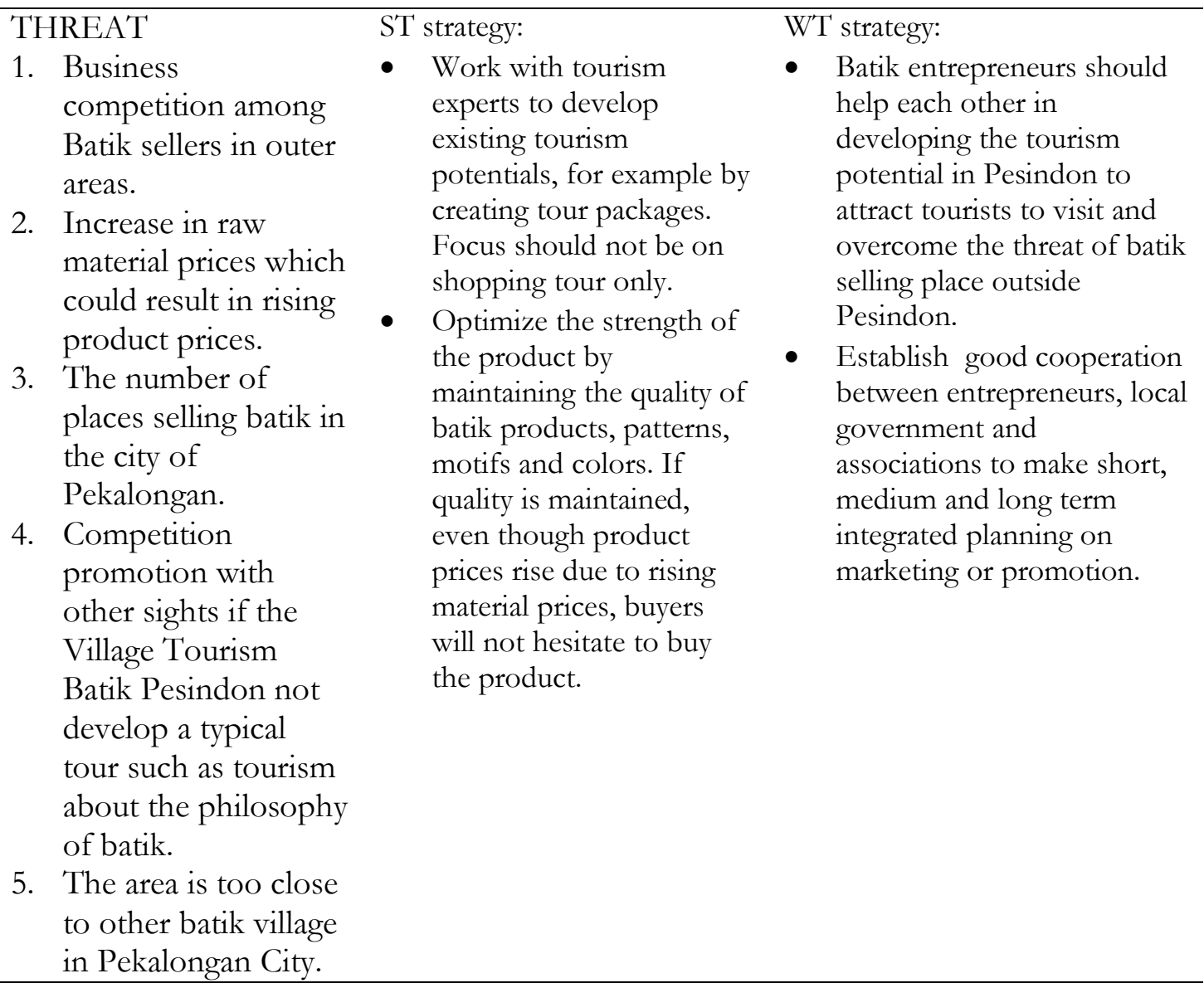

\section{F. Conclusion}

KWBP has been declared by a local government to be a tourist village with the existing potential such as a number of batik in the area. However, KWBP has not become the main destination for tourists to come. Therefore, strategies to develop the area need to be investigated and implemented. Based on SWOT analysis of KWBP, strategies to develop the area can be implemented in three areas, namely human resources development, product development, and marketing development strategies.

\section{REFERENCES}

Ismayanti. (2010). Pengantar Pariwisata. Jakarta: PT Gramedia Widisarana Indonesia

Mappi, S.. (2001). Cakrawala Pariwisata. Jakarta. Balai Pustaka

Tourism Research Journal, Volume 2 (1), 2018 
Rangkuti, F. (2009). Analisis SWOT, Teknik Membedah Kasus Bisnis. Jakarta: PT Gramedia Pustaka Utama

Ronchetti. (2006). An Integrated Balanced Scorecard Strategic Planning Model For Nonpofit Organizations. Journal of Practical Consulting. Vol.1.1ss1.2006.pp.25-35. School of Global Leadership \& Entrepreneurship, Regent University.

Salusu. (2000). Pengambilan keputusan stratejik: untuk organisasi public dan organisasi non profit. Jakarta: Grasindo

Singarimbun, M. \& Effendi, S. (1989). Metode penelitian survai. Jakarta: LP3ES.

Snelling, J. (2012). The influencey of the SWOT ANALYSIS in Organizational Development Strategic Planning. California: North Central University.

Sugiyono. (2007). Metode Penelitian Pendidikan Pendekatan Kuantitatif, Kualitatif dan R\&D, Bandung: ALFABETA

Suprina, R., Pradhipta, A. \& Pramanik, P.D. (2018). How to Manage Urban Tourism of Kampung Sumbawan, Krapyak, Pekalongan; A SWOT Analysis and Related Strategies. Proceedings of $2^{\text {nd }}$ International Conference on Tourism, Gastronomy, and Tourist Destination. March, 2018. pp 170-179

Yoeti, O.A. (1996). Pengantar Ilmu Parivisata. Penerbit Angkasa.Bandung 